\title{
Meningitis as the presenting symptom of pituitary adenomata
}

\author{
R. G. LASCELLES \\ M.D., M.R.C.P., D.P.M. \\ K. K. BHALLA \\ M.D., M.R.C.P.
}

\author{
S. J. TUCK \\ M.B., Ch.B. \\ Paul S. Graves \\ M.B., B.S.
}

\section{The Crumpsall Neurological Unit, Manchester}

\begin{abstract}
Summary
We have recently seen two patients, both men in their forties, who presented with a clinical picture of meningitis which was later found to be secondary to infarction of an underlying chromophobe adenoma of the pituitary.
\end{abstract}

THE common presentation of pituitary tumours is with the gradual onset of visual impairment, often in patients in whom there is evidence of endocrine abnormality. Infarction or haemorrhage of a pituitary tumour which has hitherto been clinically silent can result in the dramatic syndrome known as pituitary apoplexy. The onset is characterized by severe headache, vomiting, pyrexia, drowsiness leading sometimes to coma and associated with ophthalmoplegia and sudden blindness.

\section{Case no. 1}

A 45-year-old man was watching the Cup Final on television when he found the light of the screen was hurting his eyes. He continued to watch with sunglasses but gradually developed a severe bifrontal headache with neck stiffness. He retired to bed but next morning found his neck very stiff. His headache was worse and he was feverish. These symptoms progressed throughout the day; he began to vomit and the vision in his left eye blurred and then blacked out completely. He was admitted to Bury General Hospital on 8 May 1972.

On admission he was found to be drowsy with a temperature of $38.6^{\circ} \mathrm{C}$ and with marked signs of meningeal irritation. His left pupil was fixed and dilated. His CSF was under normal pressure with a protein of $108 \mathrm{mg} / 100 \mathrm{ml}$, a normal sugar and 70 polymorphs $/ \mathrm{mm}^{3}$. He was treated for meningitis with penicillin and sulphadimidine and a repeat examination of the CSF a few hours later showed the polymorph count to have risen to $1400 / \mathrm{mm}^{3}$. No organisms were found, and none seen on special staining.

Information then emerged that he had complained to his general practitioner of impotence 1 year previously and had been treated successfully with steroids. A skull X-ray (Fig. 1) was then carried out and revealed a ballooned pituitary fossa. The patient was transferred at once to Crumpsall Hospital. Examination revealed a drowsy patient with neck stiffness, a grossly impaired left visual acuity and a right homonymous hemianopia. A left oculomotor palsy was present.

On the following day, Mr Maslowski operated and found a haemorrhagic pituitary tumour extending forward beneath the optic chiasma and displacing both optic nerves. The tumour was removed and the histological appearances were compatible with an infarcted and haemorrhagic chromophobe adenoma.

The patient made an excellent post-operative recovery on replacement therapy, with the exception of his visual symptoms.

\section{Case no. 2}

This 48-year-old man was admitted to Crumpsall Hospital as an emergency on 7 August 1971. At lunch-time that day, he had drunk 2 pints of beer

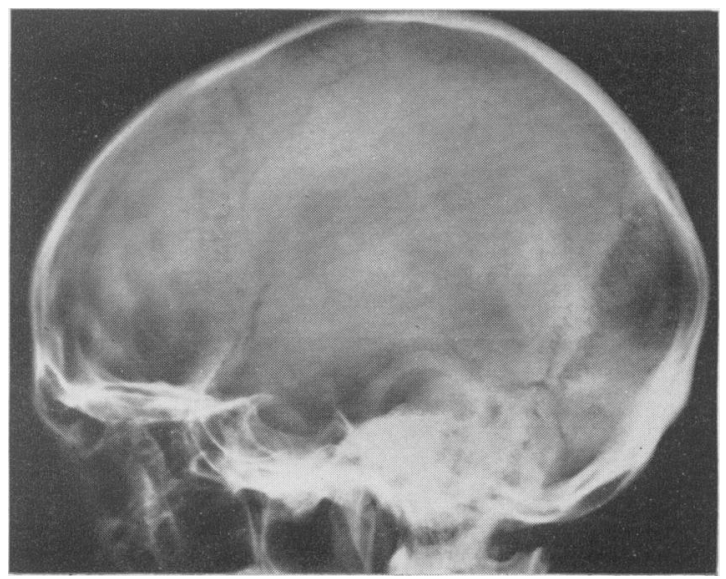

FIG. 1. Ballooning of the pituitary fossa. 
and suddenly felt nauseated. This was followed by vomiting and, over the next hour, he developed a severe left frontal headache. This headache increased in severity and the vision in his left eye became blurred.

On admission, he was drowsy with severe neck stiffness. He had a complete left ophthalmoplegia with sensory impairment over the ophthalmic division of the fifth nerve. The diagnosis was thought to rest between subarachnoid haemorrhage and meningitis, but examination of the CSF did not substantiate this (normal pressure, protein $32 \mathrm{mg}$, sugar $80 \mathrm{mg} / 100 \mathrm{ml}$, no cells).

The patient's condition deteriorated with increasing drowsiness and pyrexia and a second lumbar puncture done $6 \mathrm{hr}$ later revealed a slightly xanthochromic fluid with 700 polymorphs $/ \mathrm{mm}^{3}$. He was then treated as a possible case of bacterial meningitis but when the skull X-ray revealed a grossly enlarged pituitary fossa, urgent neurosurgical opinion was sought. A left carotid arteriogram (Fig. 2) showed marked stretching of the carotid syphon and $\mathrm{Mr}$ Maslowski performed a craniotomy. He discovered a large necrotic pituitary tumour which on histology was shown to be an infarcted chromophobe adenoma.

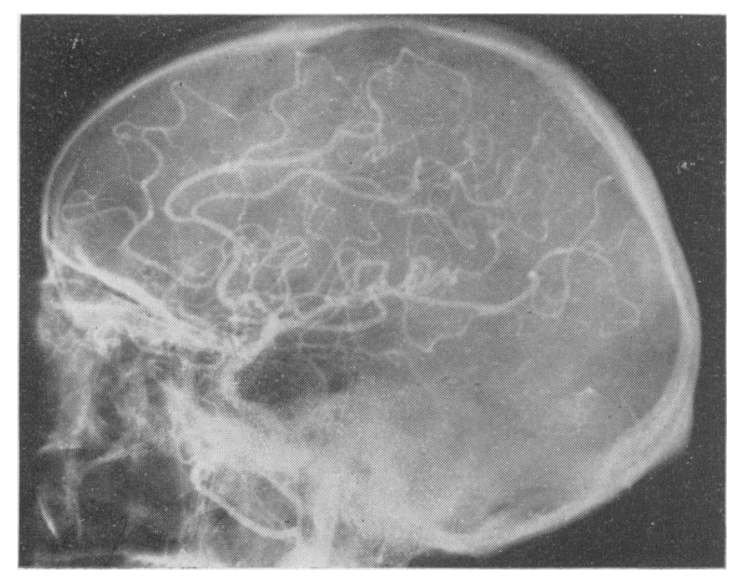

FIG. 2. Elevation and forward displacement of the carotid syphon.

The patient's post-operative recovery on replacement therapy was uneventful and his ophthalmoplegia had improved considerably when he was reviewed 2 months later.

\section{Discussion}

Pituitary apoplexy is uncommon. In a series of 117 consecutive pituitary tumours analysed by Nurnberger \& Korey in 1953, no instances were found. The first description of this condition was in
1905 by Bliebtreu, in a patient with acromegaly. Interest in this syndrome then seemed to wane until Brougham, Heusner \& Adams, in 1950, reported five new cases. Since that time, there have been a number of reports in the literature and some excellent review articles-notably by Argires \& Nelson (1966), Lopez (1970) and Epstein et al. (1971). Onsets at variance with the classical picture have been described and include subarachnoid haemorrhage (Kirshbaum \& Chapman, 1948), hemiplegia and aphasia (Brougham et al., 1950; Epstein et al., 1971), monocular blindness (Vailati, Dawley \& Evans, 1970) and sudden death (Dingley, 1932; Monro, 1913).

Severe meningeal irritation has been a conspicuous feature in some case reports (Jefferson \& Rosenthal, 1959; Epstein et al., 1971) and a meningitic picture as the presenting feature of hypopituitary coma has been noted (Pearce et al., 1964). Meadows (1968), in a report based on six patients with apoplexy, mentioned that the clinical picture could resemble that of meningitis. The cellular rise in the CSF was due to a 'chemical meningitis' or a reaction of the fluid to contact with infarcted and necrotic tumour tissue.

In their comprehensive review, Argires \& Nelson (1966) attempted to assess the CSF findings in the cases reported, but found this difficult because of the lack of details - they concluded 'when reported xanthochromic or bloody fluid was a frequent finding along with pleocytosis.'

Our patients were both originally diagnosed and treated as suffering from bacterial meningitis and we would like to stress the importance of obtaining skull radiography at an early stage in all such instances-especially as immediate surgical intervention can be life-saving.

\section{Acknowledgments}

Our thanks are due to Dr R. S. Savidge and Dr M. H. Oelbaum for referring their patients to us, and to Dr L. A. Liversedge for his helpful comments.

\section{References}

Argires, J.P. \& Nelson, J. (1966) Pituitary apoplexy: Review of the literature and two case reports. Southern Medical Journal, 59, 785.

BliebTReU, L. (1905) Ein Fall von Akromegalie (Zerstörung der Hypophysis durch Blutung). Münchener medizinische Wochenschrift, 52, 2079.

Brougham, M., Heusner, A.P. \& Adams, R.D. (1950) Acute degenerative changes in adenomas of the pituitary body-with special reference to pituitary apoplexy. Journal of Neurosurgery, 7, 421.

Dingley, L.A. (1932) Sudden death due to a tumour of the pituitary gland. Lancet, ii, 183.

Epstein, S., Pimstone, B.L., De Villiers, J.C. \& Jackson, W.P.M. (1971) Pituitary apoplexy in five patients with pituitary tumours. British Medical Journal, 2, 267. 
Jefferson, M. \& Rosenthal, F.D. (1959) Spontaneous necrosis in pituitary tumour. Lancet, i, 342.

Kirshbaum, J.D. \& Chapman, B.M. (1948) Subarachnoid hemorrhage secondary to a tumor of the hypophysis with acromegaly. Annals of Internal Medicine, 29, 536.

LOPEZ, I.A. (1970) Pituitary apoplexy. Journal of the Oslo City Hospital, $20,17$.

Meadows, S.P. (1968) Unusual clinical features and modes of presentation in pituitary adenoma, including pituitary apoplexy. In: Neuro-ophthalmology, Vol. IV. Symposium of the University of Miami and the Bascom Palmer Eye Institute. C.V. Mosby, St Louis.
MonRo, J.D.R. (1913) A case of sudden death; tumour of pituitary body. Lancet, ii, 1539.

Nurnberger, J.I. \& Korey, S.R. (1953) Pituitary Chromophobe Adenomas. Springer, New York.

Pearce, J.M.S., Swanson, I., Balla, J.I. \& Foster, J.B. (1964) Meningism and pituitary coma. Postgraduate Medical Journal, 40, 610.

Vailati, G., Dawley, J.A. \& Evans, P. (1970) Monocular blindness in a case of pituitary apoplexy. Acta neurologica, 25, 275.

\section{Pleural effusions and yellow nails of late onset}

\author{
H. D. Eastwood \\ M.B., M.R.C.P.
}

\author{
T. J. WiLliamS \\ M.B., B.Ch.
}

\section{Department of Geriatric Medicine, Southampton General Hospital}

\begin{abstract}
Summary
Recurrent pleural effusions have recently been described associated with a generalized deficiency of lymphatic drainage. A case is reported which is of interest as, though evidence of such a deficiency had been present as lymphoedema of the legs since childhood, further manifestations of this in the form of discoloured nails and recurrent pleural effusions developed in the eighth and ninth decades.
\end{abstract}

\section{Case report}

In 1962, at the age of 78, a lady was referred to the dermatological out-patients with discoloured finger nails which had been present for the preceding 6 months. The condition has persisted since then, with the principal abnormalities affecting the index fingers. The nails of these fingers showed yellowishgreen discolouration, transverse ridging and excessive side-to-side curvature. The other finger nails were affected to a lesser extent. At that time, she was otherwise well, apart from oedema of both ankles which had been present since childhood.

Subsequently, she had several admissions to hospital with episodes of acute bronchitis and broncho-pneumonia. In 1968, she was admitted with bronchitis and was found to have bilateral pleural effusions. These were drained and did not immediately recur. Two years later, however, she was readmitted with shortness of breath and found to have developed further effusions which also appeared to have followed an episode of bronchitis. No other cause for the effusions was found and they were again successfully treated by aspiration. In November 1971, she was again admitted with progressive dyspnoea, associated with a fortnight's cough and the expectoration of greenish sputum.

On examination, she was an alert 87-year-old dyspnoeic at rest but not cyanosed. She was nof clinically anaemic and there was no evidence of skin rash, nor of an arthritis. The nail changes already described were again noted. Clubbing was not present. Her pulse was regular, $74 / \mathrm{min}$, BP $140 / 80 \mathrm{mmHg}$. The ankle oedema noted previously was present but there was no other evidence of congestive heart failure. The JVP was not raised and there was neither hepatomegaly nor ascites. The apex beat was not palpable. The heart sounds were normal. There was evidence of large bilateral pleural effusions. The rest of the findings on examination were normal for a woman of her age.

\section{Investigation}

Hb $14.3 \mathrm{~g} / 100 \mathrm{ml}$; WBC $5900 / \mathrm{mm}^{3}$; ESR $30 \mathrm{~mm} /$ $1 \mathrm{hr}$; blood urea $34 \mathrm{mg} / 100 \mathrm{ml}$ with normal electrolytes. There was no proteinuria. Plasma proteins $6.9 \mathrm{~g} / 100 \mathrm{ml}$; albumin $4.4 \mathrm{~g} / 100 \mathrm{ml}$; globulin $2.5 \mathrm{~g} /$ $100 \mathrm{ml}$. The anti-nuclear factor (ANF) test was negative and her protein-bound iodine was normal at $6.2 \mu \mathrm{g} / 100 \mathrm{ml}$. The ECG showed sinus rhythm with occasional ventricular ectopic beats with complexes of low voltage. The chest X-ray after aspiration showed no evidence of an underlying lung lesion, though the heart size was slightly increased.

Gynaecological examination excluded an ovarian lesion.

The effusions were again aspirated and strawcoloured fluid with a protein content of $4 \cdot 8 \mathrm{~g} / 100 \mathrm{ml}$ obtained. A similarly high protein content had been 